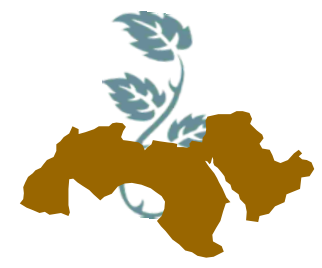

\title{
EVALUATION OF DIRECT-FED MICROBIAL SUPPLEMENTATION TO IMPROVE UTILIZATION OF THE LOW QUALITY ROUGHAGES IN RUMINANTS
}

\author{
[137] \\ Marwa A. Madkour ${ }^{1}$, Khattab ${ }^{2}$ H.M., El-Bordeny ${ }^{2}$ N.E. and Badr E. Mattar ${ }^{1}$ \\ 1- Animal Nutrition Dept., Animal Production Research Institute, Dokki, Giza, Egypt \\ 2- Animal Production Dept., Fac. of Agric., Ain-Shams Univ., P.O. Box 68 Hadayek Shoubra \\ 11241, Cairo, Egypt
}

Keywords: lambs, DFM, feed intake, digestibility, rumen contents activity, growth performance

\section{ABSTRACT}

Direct-fed microbials (DFM) feed additives have been shown to improve average daily gain (ADG) and feed efficiency in ruminant animals in many studies. So, this study aimed to evaluate effect of using fungal and bacterial DFM and their mixture on productive performance of growing lambs. Thirty-two Barkey lambs (3 months old, $22.31 \pm 1.57 \mathrm{~kg}$ ) were randomly assigned into four groups, 8 lambs of each according to live body weight. The first group (control) was fed control rations without DFM supplementation, while treated groups (Fungal DFM, Bacterial DFM and Mixed DFM) were fed the control ration plus $2.5 \mathrm{~g}$ fungal, bacterial or mixed (1:1) DFM; respectively. Results showed that groups fed ration supplemented with DFM (fungal, bacterial and mixed) recorded higher DM, TDN and digestible CP intake. Supplementation of lambs ration with DFM (fungal, bacterial and mixed) showed not significant $(P>0.05)$ effects on rumen liquor TVFA's and ammonia concentration at 0,3 and $6 \mathrm{hrs}$ post feeding. While DFM supplemented rations showed significant higher rumen liquor $\mathrm{pH}$ at 0,3 and $6 \mathrm{hrs}$ after feeding compared to the control group. Numerically increase was recorded in cellulose activity as unit per $\mathrm{ml}$ rumen liquor for groups fed ration supplemented with bacterial and mixed DFM. Direct fed microbial supplementation significantly $(P<0.05)$ improved nutrients digestibility as dry matter, organic matter, crude protein, crude fiber, nitrogen free extract, neutral detergent fiber (NDF) and acid detergent fiber (ADF) as well as feeding values as TDN and digestible crude protein. Bacterial or mixed DFM supplementation showed numerically increased $(P>0.05)$ in plasma total protein concentration compared to lambs fed ration not supplemented. While albumin, globulin, urea, triglycerides, creatinine ALT and AST, alkaline phosphates activity were not significantly $(P>0.05)$ affected by DFM supplementation. Total gain and ADG were significantly increased $(P \leq 0.05)$ for groups received rations supplemented with DFM compared to control group. Also DFM supplementation significantly $(P \leq 0.05)$ improved feed conversion as DM, TDN, $\mathrm{CP}$ and DCP compared to the control group. It could be concluded that supplementing lambs ration with fungal, bacterial or mixed DFM improved feed intake, digestibility, average daily gain and feed conversion without any adverse effects on animal health and performance.

\section{INTRODUCTION}

Improvements of animal productivity, feed utilization and animal health are the aims of rumen microbial studies. These aims could be achieved by producing desirable fermentation products as direct fed microbial (DFM). Many of the feed additives have been used to improve animal productivity and feed utilization efficiency. The probiotics (direct-fed microbial, DFM) are microbial growth promoters that could be manipulating the rumen fermentation characteristics in intestinal tracts of livestock animals (Weiss et al 2008). 
The name probiotic comes from the Greek 'pro bios' which means 'for life'. The term "probiotic" has been defined as "a live microbial feed supplement, which affects beneficially of the host animal through improving the microbial balance in the intestine" (Fuller, 1989). Also, they are known as direct-fed microbial (DFM). Probiotic or DFM have been used to describe viable microorganisms, culture extracts, enzymes, exopolysaccharides or various combinations of them (Yoon and Stern, 1995).

Direct-fed microbials (DFM) have been shown to improve average daily gain and feed conversion efficiency in feedlot animal (Krehbiel et al 2003), increase milk production in dairy cows (Oetzel et al 2007 and Chiquette et al (2008)), and improve health and performance of young calves Adams et al (2008, Dicks and Botes, (2010) and Frizzo et al (2010).

Many factors, such as the microbial type and strain, presence of enzymes in the products, their mode of action and level of application, the animal type, diet and energy level as well as animal productivity may affect animal response to DFM supplementation. Moreover few researches has been found to evaluate effect of using DFM on small ruminant performance, Also no available researches have been found to evaluate effect of using DFM on the low quality roughage efficiency of utilization.

So, this study was conducted to evaluate effect of supplement fungal or bacterial DFM or their mixture supplementation on productive performance of growing lambs fed low quality roughage (wheat straw).

\section{MATERIALS AND METHODS}

The present study was carried out in Al-Fayroz farm for agriculture and animal production, ElNoubaria, El-Behaira governorate and labs of Animal Nutrition, Animal Production Department, Faculty of Agriculture, Ain Shams University, Egypt. Preparing of the direct fed microbial (DFM) products.

Ten $\mathrm{ml}$ containing $10^{8} \mathrm{CFU} / \mathrm{ml}$ of each standard inoculum (Phanerochaete chrysosporium NRRL11460 as a fungus and Bacillus subtilus as a bac- teria) were used separately to inoculate $2000 \mathrm{ml}$ Erlenmeyer flasks containing $1000 \mathrm{ml}$ of the selective medium for each strain under investigation, and then incubated on rotary shaker (150 rpm). Incubation period was different according to the strain used to produce broth culture media of each of the tested strain, having a cell load $10^{12} \mathrm{CFU} / \mathrm{ml}$ for Bacillus subtilus while the fungs (Phanerochaete chrysosporium) were calculated as $0.06 \mathrm{~g}$ dray weight/ $10 \mathrm{ml}$. A constant volume $(4000 \mathrm{ml})$ from each strain was used to inoculate constant weight of talk powder $(2000 \mathrm{~g}$ ) each of them separately and let to dry under room temperature (25응 C). The inoculums were added to the talk powder in intervals. Cellulase activity was determined according to Lone et al (2012). The cellulase enzyme activity was $75.5,81.39$ and 78.00 unit per 1 gm fungal, bacterial and mixed MDF, respectively.

\section{Animals, and experimental design}

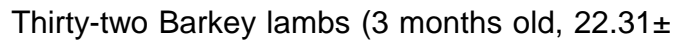
$1.57 \mathrm{~kg}$ body weight) were randomly assigned to four groups, 8 lambs for each according to live body weight. Each group was assigned randomly to receive one of the four experimental treatments. The animals were fed restricted amount of concentrate feed mixture (CFM) to cover about $80 \%$ of their allowances according to NRC (1985) and the wheat straw was offered free choice. The concentrate feed mixture (CFM) consisted of $40.5 \%$ yellow corn grain, $11.2 \%$ soybean meal, $11.2 \%$ wheat barn, $22.2 \%$ sun flower meal, $11.2 \%$ wheat, $0.2 \%$ dicalcium phosphate, $0.1 \%$ salt, $1 \%$ linestone, $0.3 \%$ yeast, $0.1 \%$ ammonium chloride, $1 \%$ mineral mix, $1 \%$ sodium bicarbonate and $0.2 \%$ detoxification agent. The first group (control) was fed control rations without DFM supplementation, while treated groups were fed the control ration plus $2.5 \mathrm{~g}$ fungal, bacterial or mixed (1:1) DFM, respectively. The chemical composition of the experimental ration ingredients are presented in Table (1). Complete rations were offered twice daily at 7 am and $4 \mathrm{pm}$ in quantities sufficient to allow free choice access to the ration, and animals have free access to clean fresh water. The growth phase lasted 124 days, the animals were weighed monthly to calculate total gain, daily gain and feed conversion. 
Evaluation of direct-fed microbial supplementation to improve utilization of the low quality roughages in ruminants

Table 1. chemical composition of the experimental rations ingredients (\%) on DM basis

\begin{tabular}{|l|c|c|}
\hline \multicolumn{2}{|c|}{ Item } & Rations ingredients \% \\
\hline \multicolumn{2}{|c|}{ CFM $^{\mathbf{1}}$} & Wheat straw \\
\hline Organic matter (OM) & 94.71 & 90.16 \\
Ash & 5.29 & 9.84 \\
Crude protein (CP) & 18.59 & 4.12 \\
Ether extract(EE) & 3.97 & 1.83 \\
Crude Fiber (CF) & 11.14 & 36.46 \\
Nitrogen free extract (NFE) & 61.01 & 47.75 \\
Non fiber carbohydrate (NFC) & 39.91 & 4.73 \\
\hline Cell wall constituents & 32.23 & 83.14 \\
\hline Neutral-detergent fiber (NDF) & 13.67 & 54.39 \\
Acid- detergent fiber (ADF) & 4.10 & 7.82 \\
A cid-detergent lignin (ADL) & 3.07 & 7.59 \\
Lignin & 18.56 & 28.75 \\
Hemicellulose & 9.57 & 46.57 \\
Cellulose &
\end{tabular}

1 CFM: Concentrate feed mixture

\section{Digestibility trials}

Through the entire experimental period, the digestibility trial was performed after two months of the experimental beginning, six animals from each treatment were used and fecal bag technique was applied. Fecal collection bags were fixed on the lambs and after a 3-day adaptation period, total feces were collected for 5 consecutive days. Fecal collection bags were emptied twice daily and the contents weighed. Total feces were sub-sampled at a percentage set for individual lambs to obtain approximately $100 \mathrm{~g}$ of fecal DM from each animal over the five days collection.

\section{Rumen parameters}

After 45 days of experimental beginning rumen contents were sampled from 5 animals of each group by stomach tube. Samples were collected before the morning feeding (i.e., $t=0$ ), 3 and $6 \mathrm{~h}$ after the morning feeding. The collected rumen fluid was squeezed through four layers cheesecloth and immediately after rumen liquor filtration; $\mathrm{pH}$ value was measured using $\mathrm{pH}$-meter (Hanna, Italy). Ammonia concentration was carried out by a modified Nessler's method modified by Szumacher-Strabel et al (2002). Frozen rumen liquor samples were analyzed for total volatile fatty acids (TVF's) by steam distillation according to Warner (1964).

\section{Chemical analysis}

Feeds and feces samples were subjected to proximate chemical analyses (crude protein (CP), crude fiber (CF), ether extract (EE) and Ash) according to AOAC, (2000) while nitrogen free extract (NFE) was calculated by difference. The NDF, ADF and ADL were determined according to Van Soest et al (1991). Cellulose and hemi-cellulose were calculated by difference and non-fiber carbohydrate (NFC) was calculated according to following equations:

Cellulose, $\%=\%$ ADF - $\%$ ADL

Hemi-cellulose, $\%=\%$ NDF-\% ADF.

$\mathrm{NFC}, \%=100-(\% \mathrm{ND}+\% \mathrm{CP}+\%$ fat $+\%$ ash $)$ (NRC, 2001).

\section{Blood parameters}

At the end of growth trial, blood samples were taken from 5 animals for each group. A sample of $10 \mathrm{ml}$ of blood was withdrawn from the jugular vein of each animal. The blood sample was directly collected into a clean dried glass culture tubes (after addition of heparin as an anti-coagulant) at 3 hrs post feeding. The blood plasma was harvested by centrifuging the collected blood samples soon after collection at about 4000 (rpm) for 15 minutes. The blood plasma was harvested into a clean dried $2 \mathrm{ml}$ ependorph tube and then stored at $-18^{\circ} \mathrm{C}$ for subsequent chemical analysis. Blood plasma samples were analyzed using commercial kits. 


\section{Statistical analysis}

The data were statistic analyzed using the statistical analysis system (SAS, 1999). Separation among means was carried out according to Duncun Multiple Range test (Duncan, 1955). Data of total and daily gain, digestibility, feed conversion and some blood parameters were statistically analyzed according to the following model: $Y_{i j}=\mu+T_{i}$ $+e_{i j}$, Where $y_{i j}=$ represents observation, $\mu=$ : the overall mean, $\mathrm{T}_{\mathrm{i}}=$ effect of treatment (experimental group), e e

While the data of rumen fermentation parameters were statistically analyzed according the following model: $Y_{i j}=\mu+T_{i}+S+a n(t)+S^{\star} T+e_{i j}$ Where: $Y_{i j}=$ The observation on the $I^{\text {th }}$ treatment, $\mu$ $=$ Overall mean, $T_{i}=$ Effect of the $I^{\text {th }}$ treatment, $\mathrm{S}=$ Effect of the period, an $(t)=$ Effect of the animal in the treatment and $\mathrm{e}_{\mathrm{ij}}=$ Random experimental error

\section{RESULTS AND DISCUSSION}

\section{Nutrient digestibility}

Direct fed microbes (DFM) supplementation significantly improved nutrients digestibility as dry matter, organic matter, crude protein, crude fiber and nitrogen free extract content (Table 2). Also, DFM supplementation improved, neutral detergent fiber (NDF), acid detergent fiber content (ADF), cellulose and hemicellulose digestibility by about 6.73 and $18.14 \%$ compared to control.
Nutritive values in term of total digestion nutrients (TDN), digestible crude protein were significantly improved with rations supplemented by DFM compared to control ration. The improvement of nutritive values (TDN and DCP\%) of rations supplemented with DFM may be due to the improvement of nutrients digestibility as shown in Table (2). Other reports have also shown improvement in dry matter digestibility and fiber with fibrolytic enzyme addition (Gado and Salem, 2008 and Hristov et al 2008). Bowman et al (2002) reported an increase in total NDF digestibility at rate $25 \%$ with a fibrolytic enzyme product. Exogenous fibrolytic enzymes (EFE) supplementation would be expected to improve fiber digestion by increasing ruminal digestion rate of the potentially NDF fraction digestibility (Yang et al 1999), alterations of rumenfermentation (Nsereko et al 2002) and/or enhanced colonization and attachment of ruminal microorganisms to plant cell wall (Nsereko et al 2000; Wang et al 2001).

However, increased fiber digestibility is unlikely due to supplemental enzyme activity alone because the contribution of added EFE to total ruminal enzyme activity is relatively very small (Beauchemin et al 2001). Wang et al (2001) reported that EFE supplementation increased numbers of total bacteria (non-fibrolytic and fibrolytic) in an in vitro batch culture system. Stimulation of rumen microbial counts by the use of EFE could result in higher microbial biomass production, consequently, provide more total polysaccharidase activity in the digested feedstuffs.

Table 2. Effect of lamb's ration supplementation with different DFM's on nutrient digestibility coefficients

\begin{tabular}{|c|c|c|c|c|c|c|}
\hline Item & Control & Fungal DFM & Bacterial DFM & Mix DFM & SE & P valu \\
\hline Dry matter, \% & $68.37^{b}$ & $72.87^{\mathrm{a}}$ & $72.45^{\mathrm{a}}$ & $72.9^{a}$ & 0.632 & 0.0003 \\
\hline Organic matter, \% & $70.27^{b}$ & $74.71^{\mathrm{a}}$ & $73.97^{\mathrm{a}}$ & $74.67^{\mathrm{a}}$ & 0.56 & 0.0001 \\
\hline Crude protein, \% & $64.66^{b}$ & $72.11^{\mathrm{a}}$ & $69.27^{\mathrm{a}}$ & $69.66^{\mathrm{a}}$ & 1.309 & 0.0087 \\
\hline Ether extract, \% & 79.82 & 76.26 & 76.73 & 77.29 & 2.131 & 0.6535 \\
\hline Crude fiber, \% & $55.46^{\mathrm{b}}$ & $62.39^{\mathrm{a}}$ & $60.73^{a}$ & $61.23^{\mathrm{a}}$ & 0.625 & 0.0001 \\
\hline Nitrogen free extract, \% & $77.52^{b}$ & $80.58^{\mathrm{a}}$ & $80.7^{\mathrm{a}}$ & $81.58^{\mathrm{a}}$ & 0.64 & 0.003 \\
\hline \multicolumn{7}{|c|}{ Cell wall constitutes } \\
\hline Neutral-detergent fiber (NDF) & $57.31^{\mathrm{b}}$ & $64.1^{\mathrm{a}}$ & $63.59^{a}$ & $64.68^{a}$ & 0.752 & 0.0001 \\
\hline Acid- detergent fiber (ADF) & $53.19^{b}$ & $60.41^{\mathrm{a}}$ & $61.15^{\mathrm{a}}$ & $62.03^{\mathrm{a}}$ & 0.732 & 0.0001 \\
\hline Hemicellulose & $62.89^{\mathrm{C}}$ & $70.56^{\mathrm{b}}$ & $71.61^{\mathrm{a}}$ & $74.30^{\mathrm{a}}$ & 1.104 & 0.0001 \\
\hline Cellulose & $62.42^{b}$ & $68.69^{\mathrm{a}}$ & $66.62^{\mathrm{a}}$ & $67.96^{\mathrm{a}}$ & 1.062 & 0.0041 \\
\hline \multicolumn{7}{|c|}{ Feeding value } \\
\hline Total digestible nutrient, \% & $71.31^{\mathrm{b}}$ & $75.22^{\mathrm{a}}$ & $73.69^{a}$ & $74.5^{\mathrm{a}}$ & 0.605 & 0.0023 \\
\hline Digestible crude protein, \% & $10.99^{b}$ & $12.36^{\mathrm{a}}$ & $11.07^{b}$ & $11.23^{b}$ & 0.221 & 0.0017 \\
\hline
\end{tabular}

$a, b$ and $c$ Means with different superscripts in the same row are significant different 

of the low quality roughages in ruminants

\section{Feed intake}

The experimental groups were fed restricted amount of feed (concentrate feed mixture and wheat straw, according to NRC allowances, 1985) and the orts were recorded. So the data of Table (3) clearly showed that the concentrate feed mixture (CFM) intake was the same for the four experimental groups, while wheat straw and total DM intake was higher in the groups fed rations supplemented with bacterial DFM and mixed DFM compared to the group fed control ration and that supplemented with fungal DFM. Also the data indicated that the groups fed ration supplemented with DFM (fungal, bacterial and mixed) recorded higher TDN intake and digestible CP intake. These results could be postulated to that DFM contained exogenous enzyme that increase rate of digestion and /or digestibility (Gado \& Salem, 2008 and Krueger et al 2008) also may be increased hydrolytic enzyme activity in the rumen consequently reduce gut fill and increase feed intake (Adesogan, 2005).

Table 3. Effect of lamb's ration supplementation with different DFMs on feed intake

\begin{tabular}{|l|c|c|c|c|}
\hline Item & Control & Fungal DFM & Bacterial DFM & Mixed DFM \\
\hline Concentrate feed mixture, kg/h/ d & 0.784 & 0.784 & 0.784 & 0.784 \\
Wheat straw, $\mathrm{kg} / \mathrm{h} / \mathrm{d}$ & 0.202 & 0.208 & 0.251 & 0.255 \\
Total feed intake, $\mathrm{kg} / \mathrm{h} / \mathrm{d}$ & 0.986 & 0.992 & 1.035 & 1.039 \\
Dry matter intake, $\mathrm{kg} / \mathrm{h} / \mathrm{d}$ & 0.860 & 0.865 & 0.904 & 0.908 \\
Total digestible nutrient intake, g /h/ d* & 0.708 & 0.738 & 0.759 & 0.788 \\
Crude protein intake, $\mathrm{g} / \mathrm{h} / \mathrm{d}^{*}$ & 153.4 & 154.3 & 156.5 & 155.6 \\
Digestible crude protein intake, $\mathrm{g} / \mathrm{h} / \mathrm{d}^{*}$ & 110.1 & 120.0 & 113.5 & 120.0 \\
\hline
\end{tabular}

* $=$ Calculated based on nutrients digestibility results

\section{Rumen parameters}

Supplementation of lambs ration with DFM (fungal, bacterial and mixed) showed no significantly effect on rumen liquor TVFA's and ammonia concentration at 0, 3 and 6 hrs post feeding (Table 4). In this connection Qiao et al (2009) found that adding DFM contained Bacillus subtilus resulted in increased total VFA concentration. Concerning effect of sampling time, the values of rumen TVFA's and ammonia concentration showed a normal pattern, which the highest value $(P<0.05)$ were recorded at $3 \mathrm{hrs}$ post feeding and gradually decreased to reach the lowest values at $0 \mathrm{hrs}$ of feeding (pre- feeding).This may be attributed to that fermentation process of both nonstructural and structural carbohydrates started with a low rate as a result to absence of substrate then increased with the time and reached the maximal level at 3 hrs after feeding then deceased up to the next meal, parallel to the gradually disappearance of substrate (El-Bordeny et al 2015 b).
Data of Table (4) clearly indicated that supplementation of lambs ration with different DFM significantly increased rumen liquor $\mathrm{pH}$ at 0,3 and $6 \mathrm{hrs}$ after feeding compared to the control group (not supplemented). This result may be due to the higher feed intake $(P>0.05)$ from wheat straw (table 3 ), consequently increase ruminating process and saliva excretion which enhance the buffering control and resulted in increase the $\mathrm{pH}$ value as well as the non-significant increase in TVFA's for control group compared to the group supplemented with different DFMs.

Concerning effect of sampling time, the values of rumen liquor $\mathrm{pH}$ showed a normal pattern, the mean value of rumen $\mathrm{pH}$ started high at zero time then decreased $(P<0.05)$ at $3 \mathrm{hrs}$, then increased $(p<0.05)$ again at $6 \mathrm{hrs}$ after feeding. These results may be related to fermentation processes of both nonstructural and structural carbohydrates and production of volatile fatty acids which increased with proceeding time so that affected the $\mathrm{pH}$ values to some limit until they were proportionally and relatively absorbed from the rumen wall 
resulting in decrease in $\mathrm{pH}$ value. These results agree with the conclusion of El-Bordeny et al (2015b) who stated that the $\mathrm{pH}$ values were related to TVFA's concentration in the rumen inversely. Numerically increase (not significant) was noticed in cellulase enzyme activity as unit per $\mathrm{ml}$ rumen liquor for groups fed ration supplemented with bac- terial and mixed DFM, and no differences was recorded among the different experimental groups in specific activity of Table cellulose as unit per mg protein (Table 4). This may be due topost-ingestive enzyme effects, which may improve hydrolytic activity in rumen ecosystem (Adesogan, 2005).

Table 4. Effect of lamb's ration supplementation with different DFMs on rumen fermentation kinetics

\begin{tabular}{|c|c|c|c|c|c|c|}
\hline Item & Control & Fungal DFM & Bacterial DFM & Mixed DFM & mean & SE \\
\hline \multicolumn{7}{|c|}{$\mathrm{pH}$ value } \\
\hline Before feeding (Oh) & 6.52 & 6.77 & 7.13 & 7.09 & $6.88^{\mathrm{a}}$ & 0.071 \\
\hline After 3 hours & 5.51 & 5.56 & 5.87 & 5.87 & $5.71^{c}$ & 0.075 \\
\hline $\begin{array}{c}\text { After } 6 \text { hours } \\
\text { Mean }\end{array}$ & $\begin{array}{l}5.76 \\
5.93^{\mathrm{C}}\end{array}$ & $\begin{array}{c}6.03 \\
6.13^{\mathrm{BC}}\end{array}$ & $\begin{array}{c}6.01 \\
6.34^{\mathrm{AB}}\end{array}$ & $\begin{array}{l}6.62 \\
6.34^{A}\end{array}$ & $6.11^{\mathrm{b}}$ & 0.08 \\
\hline \multicolumn{7}{|c|}{ Total volatile fatty acids concentration (TVFA's), $\mathrm{m}$ equiv. $\mathrm{dL}^{-1}$} \\
\hline Before feeding (Oh) & 7.22 & 5.12 & 4.92 & 5.32 & $5.65^{c}$ & 0.258 \\
\hline After 3 hours & 8.4 & 8.46 & 8.3 & 8.5 & $8.42^{\mathrm{a}}$ & 0.247 \\
\hline After 6 hours & 6.31 & 6.41 & 6.69 & 6.90 & $6.58^{\mathrm{b}}$ & 0.247 \\
\hline Mean & 7.31 & 6.66 & 6.64 & 6.91 & & \\
\hline \multicolumn{7}{|c|}{ Ammonia concentration, $\mathrm{mg} \mathrm{dL}^{-1}$} \\
\hline Before feeding (Oh) & 4.50 & 3.67 & 4.11 & 4.78 & $4.26^{b}$ & 0.559 \\
\hline After 3 hours & 8.95 & 9.58 & 9.86 & 9.68 & $9.52^{\mathrm{a}}$ & 0.527 \\
\hline After 6 hours & 4.12 & 3.48 & 6.34 & 7.52 & $5.36^{b}$ & 0.618 \\
\hline Mean & 5.86 & 5.58 & 6.77 & $7.328^{\mathrm{a}}$ & & \\
\hline \multicolumn{7}{|c|}{ Cellulose activity, unit $\mathrm{ml}^{-1}$} \\
\hline Before feeding (0h) & 4.99 & 6.06 & 4.53 & 3.91 & 4.87 & 2.799 \\
\hline After 3 hours & 10.24 & 11.62 & 17.73 & 7.65 & 11.81 & 2.799 \\
\hline After 6 hours & 17.46 & 12.12 & 17.11 & 26.96 & 18.41 & 2.799 \\
\hline Mean & 10.90 & 9.93 & 13.12 & 12.84 & & \\
\hline \multicolumn{7}{|c|}{ Specific activity of cellulase, unit $\mathrm{mg}^{-1}$ of protein } \\
\hline Before feeding (Oh) & 1.10 & 1.49 & 1.19 & 2.01 & 1.45 & 1.28 \\
\hline After 3 hours & 5.72 & 4.06 & 5.42 & 2.71 & 4.48 & 1.28 \\
\hline After 6 hours & 6.77 & 3.40 & 4.76 & 9.70 & 6.16 & 1.28 \\
\hline Mean & 4.53 & 2.98 & 3.79 & 4.81 & & \\
\hline
\end{tabular}

\section{Blood metabolic parameters}

Adding fungal, bacterial or mixed DFM to lambs ration showed insignificantly numerically increased $(P>0.05)$ in plasma total proteins concentration compared to lambs fed control ration (Table 5). This may be attributed to that DFM supplementation improve metabolic process as a response to increase nutrients digestibility specially, crude protein and organic matter (Table 4) as well as increase flow of microbial protein from the rumen (Yang et al 1999). Moreover, Kumar et al (1980) and Bush, (1991) postulated that blood total proteins plasma concentration is reflect the nutritional status of the animal and reported a positive corre- lation between blood total proteins concentration and dietary protein level.

Blood plasma albumin, globulin, urea, triglecride and creatinine concentration and ALT, AST, alkaline phosphates activity were not significantly $(P>0.05)$ affected by DFM supplementation to lambs ration (Table 5). The present values of AST and ALT activity indicated normal activity of the animal liver tissues; consequently, DFM supplementation in the present study had no any adverse effect on the liver function. Furthermore, Kholif et al (2012) and El-Bordeny et al (2015a) found that adding exogenous fibrolytic enzyme as a DFM to dairy buffaloes and dairy cows rations had not any significant effect on buffalo's blood metabolites. 

of the low quality roughages in ruminants

Table 5. Effect of lamb's ration supplementation with different DFMs on some blood plasma parameters

\begin{tabular}{|c|c|c|c|c|c|c|}
\hline Item & Control & $\begin{array}{c}\text { Fungal } \\
\text { DFM }\end{array}$ & $\begin{array}{c}\text { Bacterial } \\
\text { DFM }\end{array}$ & Mix DFM & SE & $P$ value \\
\hline Total protien , $\mathrm{g} \mathrm{dL}^{-1}$ & 5.885 & 6.151 & 6.439 & 6.37 & 0.264 & 0.463 \\
\hline Albumin, $\mathrm{g} \mathrm{dL}^{-1}$ & 2.751 & 2.868 & 2.71 & 2.906 & 0.114 & 0.612 \\
\hline Globulin, $\mathrm{g} \mathrm{dL}^{-1}$ & 3.134 & 3.283 & 3.729 & 3.464 & 0.291 & 0.593 \\
\hline $\mathrm{A} / \mathrm{G}$ ratio & 0.872 & 0.94 & 0.751 & 0.868 & 0.096 & 0.628 \\
\hline Urea, $\mathrm{mg} \mathrm{dL}^{-1}$ & 35 & 37.86 & 40.26 & 41.73 & 2.177 & 0.257 \\
\hline Triglycerides, $\mathrm{mg} \mathrm{dL}^{-1}$ & 103.6 & 127.4 & 98.25 & 98.43 & 18.427 & 0.645 \\
\hline Creatinine, $\mathrm{mg} \mathrm{dL}^{-1}$ & 0.7 & 0.725 & 0.6 & 0.68 & 0.14 & 0.959 \\
\hline Alkaline phosphatase, unit $\mathrm{L}^{-1}$ & 31.37 & 30.37 & 25.09 & 36.11 & 2.652 & 0.122 \\
\hline AST, unit $L^{-1}$ & 8.22 & 9.76 & 8.95 & 10.1 & 1.865 & 0.912 \\
\hline$A L T$, unit $L^{-1}$ & 63.44 & 62.12 & 61.96 & 56.96 & 1.839 & 0.105 \\
\hline
\end{tabular}

\section{Growth performance}

Total gain and average daily gain were significantly increased $(P=0.006)$ for groups received rations supplemented with DFM compared to control group (Table 6). In this connection Kowalski et al.(2009) found that adding DFM contain Bacillus subtilus to dairy calve ration increased average daily gain and final total gain. Moreover, Kritas et al (2006) fed ewes on ration supplemented with DFM and found increase in total milk yield, also Qiao et al (2009) found the same trend when feeding lactating cow on diets supplemented with DFM.
Also supplementation lambs rations with DFM significantly $(P \leq 0.05)$ improved feed conversion as DM, TDN, CP and DCP compared to the control group. These may be due to: 1) Higher intake of CP and TDN for supplemented groups compared to control group (Table 2), 2) the higher nutrients digestibility for supplemented groups compared to control group (Table 5). Moreover, the superiority of feed conversion as DM, TDN, CP and DCP for supplemented groups could be attributed to the higher values of average daily gain recorded for supplemented groups compared to control.

Table 6. Effect of lamb's ration supplementation with different DFMs on growth performance

\begin{tabular}{|c|c|c|c|c|c|c|}
\hline Item & Control & $\begin{array}{c}\text { Fungal } \\
\text { DFM }\end{array}$ & $\begin{array}{c}\text { Bacterial } \\
\text { DFM }\end{array}$ & Mix DFM & SE & $P$ value \\
\hline Initial weight, kg & 22.17 & 23.17 & 21.57 & 22.43 & 1.46 & 0.902 \\
\hline Final weight, kg & 38.33 & 43.67 & 43.00 & 44.00 & 1.97 & 0.22 \\
\hline Total gain, kg & $16.17^{b}$ & $20.50^{a}$ & $21.43^{a}$ & $21.57^{a}$ & 1.03 & 0.006 \\
\hline Average daily gain. g/ day & $130^{\mathrm{b}}$ & $165^{\mathrm{a}}$ & $173^{a}$ & $174^{\mathrm{a}}$ & 8.4 & 0.006 \\
\hline \multicolumn{7}{|c|}{ Feed conversion } \\
\hline Dry matter conversion, $\mathrm{kg} / \mathrm{kg}$ & $6.68^{\mathrm{a}}$ & $5.36^{b}$ & $5.34^{b}$ & $5.25^{b}$ & 0.29 & 0.008 \\
\hline TDN conversion, $\mathrm{kg} / \mathrm{kg}$ & $5.50^{\mathrm{a}}$ & $4.57^{\mathrm{b}}$ & $4.48^{b}$ & $4.56^{b}$ & 0.24 & 0.033 \\
\hline Crude protein conversion, g/kg & $1192.9^{\mathrm{a}}$ & $955.3^{\mathrm{b}}$ & $924.1^{b}$ & $900.0^{b}$ & 51.21 & 0.003 \\
\hline Digestible protein conversion, $\mathrm{g} / \mathrm{kg}$ & $856.2^{\mathrm{a}}$ & $742.7^{\mathrm{b}}$ & $669.8^{b}$ & $694.4^{b}$ & 38.06 & 0.016 \\
\hline
\end{tabular}

$a$ and $b$, Means with different superscripts in the same row are significant different. 


\section{CONCLUSION}

It could be concluded that supplementing lambs ration with fungal, bacterial or mixed DFM improve feed intake and digestibility, consequently increased average daily gain and feed conversion without any adverse effects on animal health and performance.

\section{REFERENCES}

Adams, M.C., Luo, J., Rayward, D., King S., Gibson, R. and Moghaddam, G.H. 2008. Selection of a novel direct-fed microbial to enhance weight gain in intensively reared calves. Animal Feed Sci. and Technology, 145, 41-52.

Adesogan, A.T. 2005. Improving forage quality and animal performance with fibrolytic enzymes. In: "Florida Ruminant" Nutrition Symposium, pp. 91-109. Cited by El-Bordeny, et al (2015a).

AOAC, 2000. Association of Official Analytical Chemists, Official Methods of Analysis, $17^{\text {th }}$ Ed. Association of Official Analytical Chemists, Washington, DC, USA.

Beauchemin, K.A., Morgavi, D.P., McAllister, T.A., Yang, W.Z. and Rode, L.M. 2001. The use of enzymes in ruminant diets. In Recent Advances in Animal Nutrition. Nottingham University Press, Loughborough, England, pp. 297-322. Cited by El-Bordeny, et al (2015a).

Bowman, G.R., Beauchemin, K.A. and Shelford, J.A. 2002. The proportion of the diet to which fibrolytic enzymes are added affects nutrient digestion by lactating dairy cows. J. Dairy Sci. 85, 3420-3429.

Bush, B.M. 1991. Interpretation of laboratory results for small animal clinicians pp. 238-249. Oxford Blackwell scientific publications, London, UK.

Chiquette, J., Allison, M.J. and Rasmussen, M.A. 2008. Prevotella bryantii $25 a$ used as a probiotic in early-lactation dairy cows: Effect on ruminal fermentation characteristics, milk production, and milk composition. J. Dairy Sci., 91, 3536-3543.

Dicks, L.M.T. and Botes, M. 2010. Probiotic lactic acid bacteria in the gastro-intestinal tract: Health benefits, safety and mode of action. Beneficial Microbes, 1, 11-29.
Duncan, D.B. 1955. Multiple range and multiple $F$ test. Biometrics, 11, 1-42.

El-Bordeny, N.E., Abedo, A.A, El-Sayed, H.M, Daoud, E.N., Soliman, H.S. and Mahmoud, A.E.M. 2015a. Effect of Exogenous Fibrolytic Enzyme Application on Productive Response of Dairy Cows at Different Lactation Stages. Asian J. Animal and Veterinary Advances. 10, 226236.

El-Bordeny N. E, Khattab, H. M; Badr. A. M and Marwa, A. Madkour, 2015b. Using of BioUpgraded rice straw in growing lambs nutrition. Asian J. Animal and Veterinary Advances. 10, 63-72.

Frizzo, L.S., Sotto, L.P., Zbrun, M.V., Bertozzi, E., Sequeira, G., Armesto, R.R. and Rosmini, M.R. 2010. Lactic acid bacteria to improve growth performance in young calves fed milk replacer and spray-dried whey powder. Animal Feed Sci. Technol. 157,159-167.

Fuller, R. 1989. A review: Probiotics in man and animals. J. Applied Bacteriology, 66, 365378.

Gado, H.M. and Salem, A.Z.M. 2008. Influence of exogenous enzymes from anaerobic source on growth performance, digestibility, ruminal fermentation and blood metabolites in lambs fed of orange pulp silage in total mixed ration. In: $59^{\text {th }}$ Annual Meeting of the European Association for Animal Production, Vilnius, Lithuania, August 24-27, 228 p. (Abstract).

Hristov, A.N., Basel, C.E., Melgar, A., Foley, A.E., Ropp, J.K., Hunt, C.W. and Tricarico, J.M. 2008. Effect of exogenous polysaccharide degrading enzyme preparations on ruminal fermentation and digestibility of nutrients in dairy cows. Anim. Feed Sci. Technol. 145,182-193.

Kholif, S.M., Gado, H.M., Morsy, T.A., ElBordeny, N.E. and Abedo, A.A. 2012. Influence of exogenous enzyme on nutrient digestibility, blood compostion, milk production and its composition as well as milk fatty acids profile in dairy buffaloes. Egyptian J. Nutrition and Feeds, 15, 13-22.

Kowalski, Z.M., Gorka, P., Schlagheck, A, Jagusiak, W., Micek, P. and Strzetelski. J. 2009. Performance of Holstein calves fed milkreplacer and starter mixture supplemented with probiotic feed additive. J. Anim. Feed Sci. 18, 399-411. 

of the low quality roughages in ruminants

Krehbiel, C.R., Rust, S.R., Zhang, G. and Gilliland, S.E. 2003. Bacterial direct-fed microbial in ruminant diets: Performance response and mode of action. J. Animal Sci., 81, 120-132.

Kritas, S.K., Govaris, A., Christodoulopoulos G. and Burriel, A.R. 2006. Effect of Bacillus licheniformis and Bacillus subtilis supplementation of ewe's feed on sheep milk production and young lamb mortality. J. Vet. Med. Series A. 53,170-173.

Krueger, N.A., Adesogan, A.T., Staples, C.R., Krueger, W.K., Kim, S.C., Littell R.C. and Sollenberger, L.E. 2008. Effect of method of applying fibrolytic enzymes or ammonia to Bermuda grass hay on feed intake, digestion, and growth of beef steers. J. Anim. Sci. 86, 882-889.

Kumar, N.U., Singh, B. and Verma, D.N. 1980. Effect of different levels of dietary protein and energy on growth of male buffalo calves. Ind. J. Anim. Sci., 51, 513-522.

Lone, M.A., Wani, M.R., Bhat, N.A., Sheikh, S.A. and Reshi, M.A. 2012. Evaluation of cellulose enzyme secreted by some common and stirring rhizosphere fungi of Juglans regia L. by DNS method. J. Enzyme Research, 3, 18-22.

NRC, 2001. Nutrient Requirements of Dairy Cattle, the $7^{\text {th }}$ revised ed. National Academy Press, Washington, DC, USA, 34 p.

NRC, 1985. National Research Council. Nutrient Requirements of sheep. The $6^{\text {th }}$ Revised Edition. National Academic of Science, Washington, D.C. USA, pp. 45-50.

Nsereko, V.L., Beauchemin, K.A., Morgavi, D.P., Rode, L.M., Furtado, A.F., McAllister, T.A, Iwaasa, A.D., Yang W.Z. and Wang Y. 2002. Effect of a fibrolytic enzyme preparation from Trichoderma longibrachiatum on the rumen microbial population of dairy cows. Can. J. Microbiol. 48, 14-20.
Nsereko, V.L., Morgavi, D.P., Rode, L.M., Beauchemin, K.A. and McAllister, T.A. 2000. Effects of fungal enzyme preparations on hydrolysis and subsequent degradation of alfalfa hay fiber by mixed rumen microorganisms in vitro. Anim. Feed Sci. Technol. 88, 153-170.

Oetzel, G.R., Emery, K.M., Kautz, W.P. and Nocek, J E. 2007. Direct fed microbial supplementation and health and performance of preand postpartum dairy cattle: A field trial. J. Dairy Science, 90, 2058-2068.

Qiao, G.H., Shan, A.S., Ma, N., Ma, Q.Q, and Sun, Z.W. 2009. Effect of supplemental bacillus cultures on rumen fermentation and milk yield in Chinese Holstein cows. J. Anim. Physiol. Anim. Nutr. 94, 429-436.

SAS, 1999. Statistical Analysis System. SAS User's Guide: Statistics. SAS Institute Inc. Editors, Cary, NC.

Van Soest, P.J., Robertson, J.B. and Lewis, B.A. 1991. Methods for dietary fiber, neutral detergent fiber and non-starch polysaccharides in relation to animal nutrition. J. Dairy Sci. 74, 3583-3597.

Wang, Y., McAllister, T.A, Rode, L.M., Beauchemin, K.A., Morgavi, D.P., Nsereko, V.L., Iwaasa, A.D. and Yang, W. 2001. Effects of an exogenous enzyme preparation on microbial protein synthesis, enzyme activity and attachment to feed in the Rumen simulation technique (Rusitec). Brit. J. Nutr. 85, 325-332.

Weiss, W.P., Wyatt, D.J. and McKelvey, T.R. 2008. Effect of feeding propionic bacteria on milk production by early lactation dairy cows. J. of Dairy Sci., 91, 646-652.

Yang, W.Z., Beauchemin K.A. and Rode L.M. 1999. Effects of an enzyme feed additive on extent of digestion and milk production of lactating dairy cows. J. Dairy Sci. 82, 391-403.

Yoon, I.K. and Stern, M.D. 1995. Influence of direct-fed microbials on ruminal microbial fermentation and performance of ruminants: A review. Asian-Austr. J. Anim. Sci. 8, 533-555. 

تقييم تأثير الإضافات الميكرويية لتحسين استخدام مواد العلف المالئة منخفضة الجودة في المجترات

[137]

مروة عاطف مدكور 1 - حمدي محمد خطاب2 - نصر السيد البرديني2 - - بدر البسطويسي مطر 1

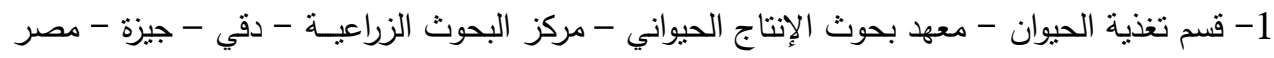

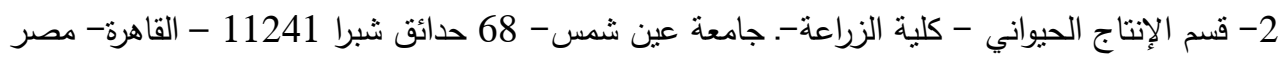

بالمجموعة الضابطة (الاولى). كما سجلت المجموعات المعات

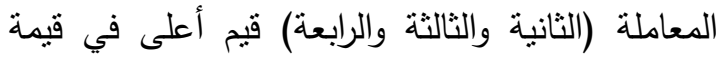
الكرش عند عند أوقات صفر و 3 و 6 ساعات الرابة فئات بعد التغذية بالمقارنة بالمجموعة الضابطة (الاولى).

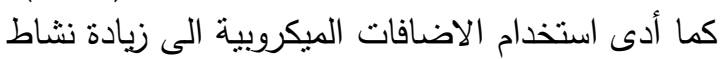
انزيم السليوليز فس سائل الكرش. أدى الدئل الستخدام

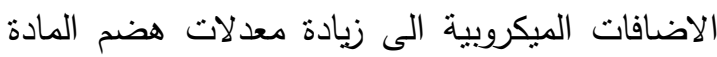
الجافة والمادة العضوية والبروتين الخام والالياف الخام ومكونات جدار الخلية بالمقارنة بالمجموعة الضابطة.

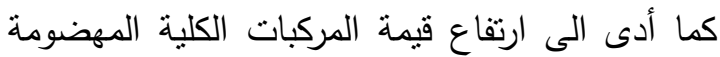
والبروتين المهضوم بالمقارنة بالمجموعة الضابطة.

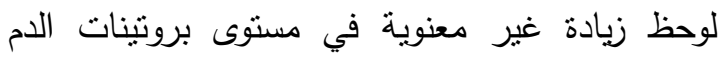

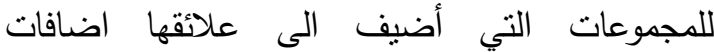
ميكروبية بالمقارنة بالمجموعة الضابطة بينما لم توجد الفيد أي فروق معنوية في تركيز الألبيومين والجلوبيولين واليوريا والجلسريدات الثلاثية. والكرياتين وانزيمات الكينية الكبد

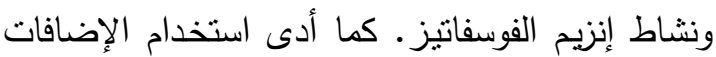

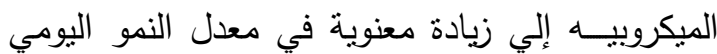

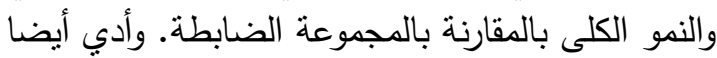
إلي تحسن فى كفاءة التحويل كمادة جافة وكبروتين

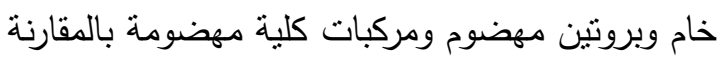
بالمجموعة الضابطة.

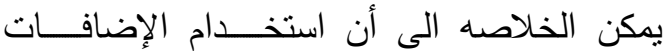
الميكروبية الفطريه والبكتيرية والمخلوط قد حسن من الفن الفين المأكول والهضم وزاد من معدلات النمو وكفاءة التحويل بدون التأثير على آداء الحيوان وصحته.
الكلمات الدالة: الحملان، الاضافات الميكروبية، المأكول، الهضم، النمو، تخمرات الكرش الاضل الخات

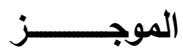

في العديد من الدراسات أدي استخدام الاضافات

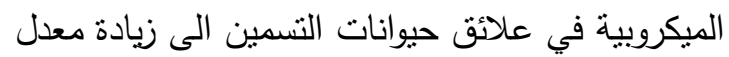

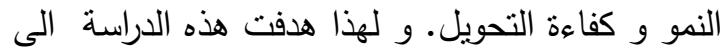

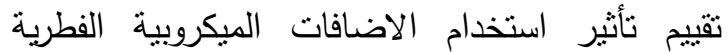
والبكتيرية والمخلوطة (1:1 فطر : بكتريا) على الآداء الانتاجي للحملان النامية. استخدم في هذه الداسلة اثثين وثلاثون حمل برقي (عمر 3 أنشهر ومتوسط وزن الانتاني 1.57×22.31) قسمت عشوائيا على أربعة مجموعات

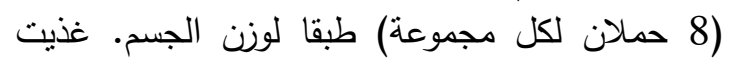

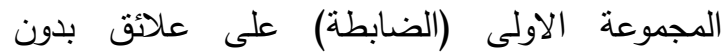
اضافات ميكروبية بينما غذيت المجموعات التجريبية الثانية والثالثة والرابعة على نفس العلائق مع استخدام

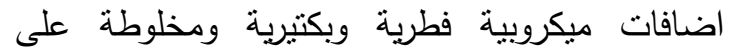

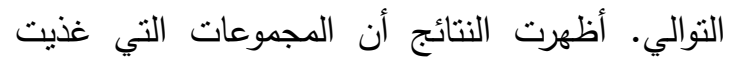
على علائق مضاف لها اضافات ميكروبية فطرية الفية

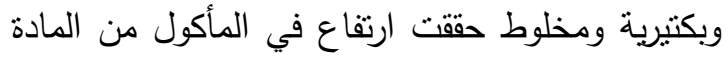
الجافة والمركبات الكلية المهضومة والبروتين المهضوم. كما لوحظ أن استخدام الاضافات الميكروبية المختلفة اليرونة المبات

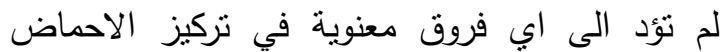

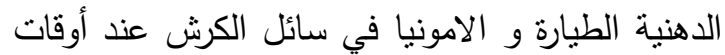
صفر و 3 و 6 ساعات بعد التغذية بالمقارنة 
1878

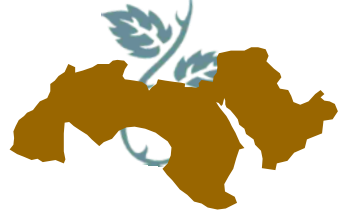

مجلة اتحاد الجامعات العربية

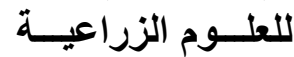

جامعة عين شمس ، الزقاهرة

مجلد(26)، عدد (2C)، عدد خاص ، 1869 - 1878، 2018

تحكيم: ا.د فـــؤاد عبد العزيــز فـؤاد

ا.د فتحية عبد العظيم إبراهيم 